\title{
Meta
}

Journal des traducteurs

Translators' Journal

\section{GENTZLER, Edwin (2017): Translation and Rewriting in the Age of Post-Translation Studies. New York: Routledge, 245 p.}

\section{Jinhui Liu et Jun Wen}

Volume 63, numéro 1, avril 2018

URI : https://id.erudit.org/iderudit/1050530ar

DOI : https://doi.org/10.7202/1050530ar

Aller au sommaire du numéro

Éditeur(s)

Les Presses de l’Université de Montréal

ISSN

0026-0452 (imprimé)

1492-1421 (numérique)

Découvrir la revue

Citer ce compte rendu

Liu, J. \& Wen, J. (2018). Compte rendu de [GENTZLER, Edwin (2017): Translation and Rewriting in the Age of Post-Translation Studies. New York: Routledge,

245 p.] Meta, 63(1), 267-269. https://doi.org/10.7202/1050530ar

Ce document est protégé par la loi sur le droit d'auteur. L'utilisation des services d'Érudit (y compris la reproduction) est assujettie à sa politique d'utilisation que vous pouvez consulter en ligne.

https://apropos.erudit.org/fr/usagers/politique-dutilisation/
Cet article est diffusé et préservé par Érudit.

Érudit est un consortium interuniversitaire sans but lucratif composé de l’Université de Montréal, l'Université Laval et l'Université du Québec à Montréal. Il a pour mission la promotion et la valorisation de la recherche. https://www.erudit.org/fr/ 
Gentzler, Edwin (2017): Translation and Rewriting in the Age of Post-Translation Studies. New York: Routledge, 245 p.

With his new book Translation and Rewriting in the Age of Post-Translation Studies, Gentzler calls for a "post-translation studies" turn in translation studies. Changes and developments in translation and translation studies urge academia to think about new directions for the field. Following the "cultural turn" proposed by Susan Bassnett and André Lefevere, and the "sociological turn" in the late 1990s Gentzler endeavors to push translation studies into a new phase.

The term "post-translation" in the book title refers to more than the literal meaning of "post." Susan Bassnett offers a philosophical explanation of "post," which signifies both the past and the new life from the past. And in the Introduction, Gentzler presents the research subject of "post-translation study" in two directions: pretranslation culture and post-translation effects.

The book has six chapters, including an important introduction, a conclusion, and four numbered chapters dealing with four case studies relative to post-translation analysis. The introduction presents the necessity for and research objects of post-translation studies. The term "posttranslation studies" coined by Siri Nwegaard and Stephano Arduini in Translation: A New Paradigm (2011), in the introduction to the first issue of a new journal called Translation, reflects the need to expand the research field of translation studies. Post-translation studies can be fruitful in exploring pre-translation conditions and post-translation effects, thus explaining why one translates in a certain way, and how new ideas are introduced to other cultures via translation. On the one hand, post-translation studies should analyze "both the initial reception of the translated text and the post-translation repercussions generated in the receiving culture over subsequent years" (p. 3). On the other hand, post-translation studies should also look at "pre-translation culture... those sociopolitical and linguistic conditions that create an environment in which highly innovative, original writing can flourish" (p. 4, emphasis in the original). In this process, researchers need to bring in perspectives from other disciplines and break the boundaries between original, translation, and rewriting.

Post-translation studies owe a great deal to deconstructionist ideas, postmodern theory, Susan Bassnett and André Lefevere's discussion on translation and rewriting, Gérard Genette's study of rewriting, and Linda Hutcheon's research on translation and rewriting in a new age, which Gentzler frequently refers to in the ensuing chapters.
Chapter 1 first discusses the relationship between translation and world literature. Their relationship is just as David Damrosch states: "World literature is an elliptical refraction of national literature" (Damrosch 2003: 281) and "World literature is writing that gains in translation" (Damrosch 2003: 22). Then, the six subsections investigate the translational nature of $A$ Midsummer Night's Dream (1600) and the ways in which this play travels across cultural borders to become a work of world literature. The first section makes a historical and social analysis of the translational culture of Elizabethan England. The second section, entitled Shakespeare as a translating author, offers a detailed text analysis of the translational markers found in A Midsummer Night's Dream. The translational culture of Elizabethan England and Shakespeare's rewriting lend to the original of A Midsummer Night's Dream a translational feature. Then, section three looks at A Midsummer Night's Dream's journey to Germany by way of traveling English actors, and shows that the play, instead of being popular at that time in England, remains alive in Germany and then in Europe through "intersemiotic means" (p. 47). Section four looks at the vibrant changes in translation of A Midsummer Night's Dream in $18^{\text {th }}$ century Germany and Europe. At the time in Germany, prominent scholars such as Lessing, Herder, Wieland, Goethe, Schiller, Tieck, and the Schlegel brothers were "translating, editing, or staging Shakespeare" (p. 48). Section five describes and analyzes considerable post-translation rewritings of the play, including Mendelssohn's musical work Overture, Max Reinhardt's theater productions in Germany and then his Hollywood film in America, George Balanchine's ballet, performed with Mendelssohn's music, and Peter Hall's film in England. The last section returns to Peter Brook's radical rewriting of A Midsummer Night's Dream (1970) in a white box, which represents the endless journey of this play. It can be found from this post-translation analysis of A Midsummer Night's Dream that the various rewritings have contributed to the global understanding of the play and this case illustrates the manner in which texts flow.

Chapter 2 is entitled Postcolonial Faust. As the title suggests, it makes a post-translation analysis of the translations and rewritings of Faust with a postcolonial perspective - cannibalism to see the multidirectional circulation of texts. Cannibalization, employed by Brazilian writers and translators, is suggested for postcolonial translators. Section one looks at the translational culture of $18^{\text {th }}$ century Germany, which produced numerous creative writers and translators whose works would influence Goethe. Goethe also learned a great deal from the translation culture 
borrowed from Greek and Roman classics and from European folklore. Section two focuses on the rewriting of Faust by Goethe himself. Section three presents the translation history of Faust into English, which involves numerous translators. Section four focuses on post-translation effects by studying a series of rewritings, from theater productions to novel adaptations, to film productions and music. Within Germany, rewritings of Faust, influenced by different ideologies and political tendencies, became a channel for different expressions and claims, alternative ideas and forms. Then, a post-colonial translation of Faust made it more international.

Chapter 3 contains a review of Susan Bassnett and André Lefevere's work on translation and rewriting and a post-translation analysis of a selected example: Proust's À la recherche du temps perdu (1908). Section one proposes to break down the distinction between translations, versions, adaptations, and rewritings. Section two analyzes the translational culture brought about by industrialization and capitalism in late nineteenthcentury Paris, which nourished Proust's curiosity and life. Section three presents a detailed study of the translational nature of $\grave{A}$ la recherche $d u$ temps perdu. Section four looks at Proust's rewriting process and shows that "originals are also in a state of rewriting" (p. 141). Section five is a translation history of $\grave{A}$ la recherche du temps perdu. Some important translations are discussed. It is through translation that Proust is enabled to enter the English literary tradition. Section 6 discusses a selection of post-translation and post-modern rewritings of $\grave{A}$ la recherche du temps perdu in a variety of media, including films, theater adaptations, illustrated books, feminist novels, abridgements, and other forms on the internet.

Chapter 4 starts by introducing the concept of "tradaptation." Translational practices and theoretical discussions among scholars has expanded the definition of translation to include different forms of rewriting like "tradaptations, transfigurations, creative interference, furtherings, and transelations" (p. 175). Then, section two studies in detail the precursors of Shakespeare's Hamlet (1609) and the author concludes that Shakespeare was actually rewriting from multiple sources. Section three analyzes the translational nature of Shakespeare's Hamlet, as is displayed in the characters, the words, and the plot of the play. Section four examines the third period of high translational activity in China, during which Hamlet was imported via Lin Shu's translation. It also discusses how to go about studying and evaluating post-translation repercussions, which is not an easy job. Section five looks at the translation history of Hamlet since 1904. Chinese translations of the play are more concerned with the image and ideology of the play and are manipulated by both social poetics and ideology. Section six goes over a few major and representative rewritings of Hamlet in theater and film, including three theater productions (the 1989 production of Hamlet in Beijing, the 1992 production Shamlet, and the 2000 version of Hamlet in Hong Kong) and two adapted films. The post-translation impacts on translation, theater, creative writing, and social engagement can be found in this section.

Gentzler's book is a pioneering work that aims to initiate a "post-translation turn" in translation studies. This volume is significant in the following aspects. First, it encourages rethinking of the nature and role of translation. Drawing on deconstruction and post-modern theories, the new concept of "post-translation" will challenge traditional definitions of translation and also the relationship between original, translation, and rewriting. In this global age, with new media and mass communication, the "goals" and "nature" of translation have changed. As Gentzler observes: "we all live in a translational culture, always in an ongoing process of movement and maneuvering, invariably traversing boundaries, changing and adapting as needed, buying, consuming, borrowing, interpreting, and translating" (p. 8). Translation is reconsidered as "one of the most important processes that can lead to revitalizing culture, a proactive force that continually introduces new ideas, forms or expressions, and pathways for change" (p. 8). In this process, the boundaries between original, translation, and rewriting become blurry and even disappear. Genztler, in this study, suggests that "all writing is rewriting, or a rewriting of a rewriting and translation intralingual, interlingual, and intersemiotic - plays a significant role in that process" (p. 10). Susan Bassnett also points out, in the foreword, that Gentzler's post-translation studies: “demands a questioning of older definitions of translation, and an end to trying to distinguish between so-called originals, translations, and rewritings" (p. ix).

Second, it expands the territory of translation studies. New research interests will emerge within post-translation studies: the study of the translational culture of the original work, translational elements of the original, the translational environment of the receiving culture, and the circulation and repercussion of translations and rewritings. Pre-original and post-translational texts, which were previously ignored in the field, either in part or in whole, will be examined in post-translation studies. Translation does not happen in a vacuum. Pretranslation culture will influence the production of translated texts as well as original texts. Thus, much more research will be done on the complicated 
cultural conditions that spawn translations. Besides interlingual translation, intralingual translation and intersemiotic translation are also included in post-translation studies. In addition, it can cover all the new forms and genres brought about by new media. Post-translation studies can include intersemiotic transfers such as cinematic, musical or other media versions and better study them.

Nevertheless, there are difficulties in carrying out post-translation studies. As Gentzler points out in his conclusion: "post-translation studies is not bound by fixed objects - source and target texts - but is more fluid and includes looking at the pre-textual components, the multilingual aspects and multicultural ideas that comprise an original" (p. 230). This process demands meticulous study and analysis, as well as a sharp mind. Moreover, post-translation repercussions are not easy to investigate: "The repercussions can be seen everywhere - in print, art, signage, fashion, food, and media - and in every discipline - literature, politics, architecture, anthropology, philosophy, and religion" (p. 231). So, comprehensive knowledge is needed to carry out such a study. Although Gentzler offers four case studies as guidance, there is not a fixed framework to follow in carrying out post-translation studies.

Despite these difficulties, post-translation studies will be a new trend. In order to make his argument forceful, Genztler has made great efforts in selecting and organizing his material. First, Genztler takes great trouble to select his four case studies, which cover a wide variety of cultural zones, namely England, Germany, France, Brazil, and China. They are also arranged chronologically: "beginning with ElizabethanAge British, followed by German romanticism, Belle Epoque French, and twentieth-century Chinese modernization" (p. 16), which makes each case study quite representative. Then, this book is quite impressive in its archeological work. There are 20 tables listing the translations, rewritings and adaptations of each work under study. These lists offer a very convincing argument for translation's place at the center of cultural circulation. It is also worth mentioning that this book is reader friendly. When discussing theatrical productions and films, pictures are provided to give the reader a direct visual perception.

Overall, Gentzler's Translation and Rewriting in the Age of Post-Translation Studies is a remarkable book. All his efforts will hopefully push translation studies forward and into a vast territory and into a new age. Researchers in translation studies and beyond will all benefit from this enlightening and challenging book.

JiNHUi LIU AND JUN WEN Beihang University, Beijing, China

\section{REFERENCES}

DAmrosch, David (2003): What is World Literature? Princeton: Princeton University Press.

NergaArd, Siri and Arduini, Stephano (2011): Translation: A New Paradigm. Translation. Inaugural Issue:8-17.

LADMIRAL, Jean-René et LiPIANSKy, Edmond Marc (2015): La Communication interculturelle. Paris: Les Belles Lettres, 330 p.

À la suite de l'épuisement de la première (1989), deuxième (1991) et troisième (1995) édition du présent ouvrage, une quatrième édition est parue en octobre 2015. Du côté du fond, cette édition prône l'osmose entre les études interculturelles et la traductologie, deux disciplines considérées à la fois connexes et distinctes dans les éditions antérieures. Quant à la forme, cette nouvelle édition a porté sur l'élimination des coquilles et l'amélioration de plusieurs formulations inadéquates tout en conservant la pagination originale.

Le seul compte rendu du livre réalisé jusqu'alors est celui de Judith Woodsworth (1990), dans $T T R$, à propos de la toute première édition de 1989, une bonne raison de se livrer de nouveau à l'exercice en se basant sur la dernière édition.

L'ouvrage est composé de trois parties et de onze chapitres. L'introduction porte sur la communication interculturelle comme enjeu et défi mondial, avec une attention particulière aux sociétés de l'Europe occidentale. Les auteurs définissent la notion de culture comme étant «les modes de vie d'un groupe social: ses façons de sentir, d'agir ou de penser; son rapport à la nature, à l'homme, à la technique et à la création artistique» (p. 8). Quant au terme «interculturel», il est défini comme "un champ interactif, où l'on s'interroge sur les relations qui s'instaurent entre groupes culturellement identifiés» (p. 10). L'interculturel ici traité s'intéresse particulièrement à l'exemple paradigmatique des relations entre Français et Allemands menées dans le cadre des "programmes de formation-recherche» commandités par l'OFAJ (Office franco-allemand pour la jeunesse). Pour ce faire, les auteurs font appel à une approche psychosociologique qui s'appuie sur la dynamique des groupes binationaux et plurinationaux et concilie pratique et empirique. Les résultats de recherche ainsi analysés posent les bases d'une analyse sémiotique et sociohistorique intitulée l'«imagologie interculturelle» (p. 15).

Dans le premier chapitre, "Pour une dynamique des groupes bilingues ", Ladmiral traite des aspects psychosociologiques du bilinguisme qu'il qualifie d' «inédits». Aidé par une équipe d'animation et de recherche bilingue et monolingue, 